\title{
O SILÊNCIO DA ESFINGE: O ERRO DE ÉDIPO E A REDESCOBERTA RESPOSTA AO ENIGMA
}

\author{
Jane Connell \\ Universidade de Melborne, Austrália \\ Édipo, filho de Laio, resolven enigmas que confundiram \\ todos antes dele, \\ a ponto da sombria profetiza, a Esfinge, se lançar do \\ penhasco, \\ jazendo agora morta, e seus enigmas, esquecidos. \\ Ovídio \\ A verdade é que o elemento material está contido no \\ feminino, \\ mas a subjetividade está contida no masculino. \\ G.W.F. Hegel
}

Uma atmosfera de triunfo paira sobre a resposta de Édipo ao enigma da Esfinge tebana e sobre a "descoberta" de Freud sobre o complexo de Édipo. Tais eventos essenciais marcam Édipo e Freud como os heróis intelectuais de suas respectivas épocas. Assim como a vitória de Édipo é entendida como instauradora da secular tradição filosófica do Ocidente, ${ }^{1}$ também o complexo homônimo demarca o percurso de influência da psicanálise na contemporaneidade. Porém, apesar da inquietação sobre o papel da Esfinge na narrativa mítica e de um difuso sentimento de incompleta resolução do enigma, persiste ainda a antiga e incômoda visão segundo a qual a derrota da Esfinge por Édipo foi um pontual sucesso intelectual. De modo similar, o fato do feminino ainda não ter sido seriamente adaptado aos ditames do desenvolvimento do esquema edipiano não prejudica a influência dominante do complexo criado por Freud, numa controvérsia que continua a assombrar suas bases. Em ambos os casos, no passado e no presente, há uma dificuldade tanto de um lado quanto de outro do feminino nunca ser inteiramente suplantado, dificuldade que ameaça minar esse ar de descomplicada vitória.

\footnotetext{
${ }^{1}$ Veja, por exemplo, HEGEL, G. W. F. Aesthetics: Lectures on Fina Art. Trad. de Thomas M. Knox.
} 2 vols. Oxford: 1975 , p. 361. 
Neste texto, o próprio mito de Édipo será usado para interrogar a problemática metáfora do feminino que permeia a crítica ao mito e ao complexo. ${ }^{2}$ Em tal leitura, a Esfinge será necessariamente recrutada de sua marginalizada posição. Apesar dela ser a interlocutora de Édipo - se instaurando diante dele como sujeito inteligente e verbal - sua posição comunicativa recebeu pouca atenção no debate sobre o enigma. Enquanto sua intencional derrota sustenta a vitória de Édipo, e, também, a credibilidade do renome de Freud, ${ }^{3}$ a pergunta da Esfinge conta muito pouco para a tradição que valoriza esses dois homens. Interpretações positivas e poderosas de Édipo e Freud são objetivadas através de uma profunda supressão de qualquer trajetória interpretativa sobre a Esfinge, o que pode ser atribuído ao seu gênero como também a sua monstruosidade - não que esses traços sejam independentes. A leitura que recusa tal supressão, talvez até uma proibição, fornece uma perspectiva radicalmente diferente, recuperando - depois de dois milênios e meio - outra resposta para seu enigma aparentemente perdido. Esta contestação - esta potencial desestabilização da segurança conferida pelas certezas edipianas de superioridade intelectual diante da criatura feminina e da sua injustificada derrota - sinaliza para cismáticas aberturas na direção de que a epistemologia ocidental tradicional não deveria impedir a exploração de uma resposta que extrapole o herói.

\section{Um ser enigmático ou uma pergunta enigmática?}

Que a resposta à pergunta da Esfinge tenha sido perdida corresponde ao comentário de Ovídio de que seus enigmas foram esquecidos (Ovídio, Metamorfoses, v. 759-6), pois existem, e existiam, muitos relatos escritos de tais enigmas. Se a observação do poeta latino revela um desconforto com a Esfinge, então essa apreensão ressurge no século XX. Em 1915, em sua extensa obra, Oidipus, Robert escreve: "A Esfinge era o problema mais grave na lógica da narrativa, um problema que os poetas nunca resolveram." 4 Nesta passagem, a criatura cujo papel é justamente o de propor a questão, transmutase no problema em si. Desta vez, a maneira respeitosa de lidar com a mulher problemática - objetificação - pavimenta o caminho para a Esfinge ser vista como um rastro para a especulação teórica, embora, como veremos, suas próprias palavras sejam negligenciadas. Edmunds vai tão longe para contestar a

\footnotetext{
2 Tal leitura baseia-se no argumento de Goux, segundo o qual é próprio mito de Édipo e da Esfinge que explica a "descoberta" de Freud do complexo de Édipo ao invés do contrário. Veja GOUX, Jean-Joseph. Oedipus, Philosopher. Trad. Catherine Porter. Stanford: 1993. A partir deste ponto abreviado como OP.

${ }^{3}$ Veja, por exemplo, GAY, Peter. Freud: A Life for Our Time. London: 1988, p. 154 e 171.

4 ROBERT, Carl. Oidipus: Geschichte E. Poetischen Stoffs im Griech. Berlin, 1915. Citado em EDMUNDS, Lowell. The Sphinx in the Oedipus Legend. Königstein: 1981, p. 12.
} 
necessidade de sua presença per se, que argumenta ser a Esfinge uma adição estranha e desnecessária ao mito. ${ }^{5}$ Todavia, também observa a sua tendência a ser re-presente:

A Esfinge, na lenda de Édipo, (...) fornece o que viria a ser durante muitos séculos o episódio mais ilustre do mito, tanto que Édipo é ainda conhecido entre os estudiosos e leigos como o grande decifrador de enigmas. Porém, com os pensadores supracitados [Freud e Lévi-Strauss], ela começa a esvanecer na obscuridade. Irá a Esfinge desaparecer, ou ela permanecerá lá, às portas de Tebas, aguardando futuros Édipos?

Mais recentemente, na esteira de Lévi-Strauss - a quem chegaremos - a representação da Esfinge como um enigma em si mesma, por vezes, traz consigo uma reabertura da questão do enigma. De Lauretis propõe

que pode muito bem ser. . q que a história tenha de ser contada de modo diferente. Tome Édipo, por exemplo, e suponha: Édipo não decifrou o enigma. ${ }^{7}$

Mulvey conclui que

certamente esse é o outro lado da moeda da angústia. A curiosidade e o espírito enigmático da Esfinge ativam perguntas que tornam acessíveis os cadeados de recalque, mantendo a força do "princípio da incerteza" (...) A história ainda está sendo contada. A Esfinge e seu enigma ainda esperam por um "além de". ${ }^{8}$

E Goux escreve:

O enigma da Esfinge? Uma expressão a ser tomada em dois sentidos: o enigma que a Esfinge propõe e aquele que a Esfinge em si constitui. Édipo pensou que tinha resolvido o primeiro; Freud, o segundo. Mas, e se nenhum dos dois tivesse encontrado a resposta??

${ }^{5}$ EDMUNDS, The Sphinx in the Oedipus Legend.

${ }^{6}$ Ibid., p. 290.

${ }^{7}$ LAURETIS, Teresa de. Alice Doesn't: feminism semiotics cinema. Bloomington: 1984, p. 156.

${ }^{8}$ MULVEY, Laura. Visual and Other Pleasures. New York: 1989, p. 200.

${ }^{9}$ GOUX, OP, p. 24. 
A Esfinge à espera torna-se um motivo estranhamente persistente, retrocedendo a sua posição pré-edípica: como se ela antecipasse seu próximo interlocutor.

É essa atmosfera de ambiguidade e falta de resolução em torno da Esfinge e de suas palavras mantida a fim de evitar o que parece ser o óbvio caminho à frente? Não é estranho levantar essa tentadora ideia - a de que o enigma da Esfinge permanece sem solução - sem considerar a sua pergunta, o enigma, em si mesmo? Entretanto, é exatamente isso que tem acontecido. A proposição de que Édipo não conseguiu responder ao enigma permanece não desenvolvida. O enigma não é reexaminado e nem sujeito a muito escrutínio. Se, de fato, a perspectiva da Esfinge, seu ponto de vista, tem o sentido de um enigma, isso passa despercebido, enquanto a alegação de que ela própria constitui um enigma é mais assumida. Talvez, a Esfinge seja um progenitor daquela outra grande evasiva sobre a mulher que a autoridade apresentou como sua própria subjetividade - o "continente negro".

\section{O enigma de Freud: a pergunta errada}

Freud não compartilha dessas incertezas sobre a Esfinge. Ele, como Édipo, supõe que ele mais do que ela tem a resposta; na verdade, acredita que sabe mais sobre ela do que ela mesma. Da forma como é trazida à baila às sombras de sua assimilação no mito de Édipo, a Esfinge é despojada de sua antiguidade, estando sujeita a uma temporária re-designação de seu gênero e tendo sua capacidade comunicativa sofrido uma inteira reescrita.

Em uma discussão sobre "a derivação do drama da lenda grega", Freud, presumivelmente com o objetivo de encontrar no mito um complexo de Édipo sobre-determinado, afirma que

o herói comete o ato sem intenção e, aparentemente, não influenciado pela mulher. Este último elemento é, contudo, tomado em consideração na circunstância de que o herói só pode obter a posse da rainha-mãe depois de ter repetido sua façanha contra o monstro que representa o pai. ${ }^{10}$

Nessa passagem, o confronto discursivo entre o homem e a mulher é recusado e reduzido à repetição da violenta altercação entre corpos masculinos. Édipo executa pela segunda vez um impulsivo golpe em direção à

${ }^{10}$ FREUD, Sigmund. "Dostoevsky and Parricide". The Standard Edition of the Complete Psychological Works of Sigmund Freud. Trad. e Ed. James Strachey, 24 vols. London: 1953-74. Vol. 21, p. 188. A partir deste ponto abreviado como SE. 
violência. A Esfinge de Freud torna-se, assim, meramente um ator em uma sórdida batalha intra-familiar - como um pai. ${ }^{11}$

Em outro texto, Freud permite a ela uma posição discursiva, mas brinca com suas palavras:

Não é por interesses teóricos, mas por práticos, que as atividades de pesquisa são definidas ainda na infância (...) O primeiro problema com o qual a criança lida não é a distinção entre os sexos mas o enigma a respeito de onde os bebês vêm. (Essa pergunta, em uma forma distorcida que pode ser facilmente corrigida, é o mesmo enigma que foi proposta pela Esfinge tebana). ${ }^{12}$

Freud reafirma esta versão reformulada do enigma várias vezes, ${ }^{13} \mathrm{com}$ frequência em uma trajetória temporal característica de seu estilo, e equacionao com o enigma da Esfinge: "O enigma da Esfinge - ou seja, a questão sobre de onde os bebês vêem." 14 Esta realocação de significado não é explicada nem justificada. Freud não interpreta esse problema; ele primeiro corrige e depois suprime as palavras da Esfinge. O enigma é rebaixado a uma questão factual, embora ainda se trate de um segredo. Sua resposta jaz em informações das quais Freud e seu leitor são partícipes, não demandando nenhum tipo de pensamento abstrato.

A inteligente e poderosa criatura que bloqueia o caminho com um desafio intelectual se transforma, assim, em uma criança ingênua questionando um pai onisciente. $\mathrm{O}$ enigma é resolvido e realocado no paradigma edipiano, assim como a própria Esfinge, agora transmutada em "pai". Parece assim que, para Freud, se a psicanálise não deve ser pensada sem Édipo, ela deve ser pensada sem a Esfinge e sem o seu enigma. ${ }^{15} \mathrm{~A}$ Esfinge pode ser um homem ou uma criança, mas o sujeito adulto e feminino que sabe a resposta a sua própria pergunta é extirpado. Tal supressão e confabulação convidam à interpretação e, como veremos, a imposição de Freud sobre o enigma da Esfinge na verdade contém uma exata negação da sua esquecida resposta.

11 Goux, fica preocupado, até mesmo irritado, com a supressão da feminilidade da Esfinge por Freud ( $O P$, p. 23), mas ignora a supressão das suas palavras.

${ }^{12}$ FREUD. "Three Essays on the Theory of Sexuality." SE 7, p. 194-5.

${ }^{13}$ Veja FREUD. "The Sexual Enlightenment of Children." SE 9, p. 135; "Analysis of a Phobia in a Five-year-old Boy," SE 10, p. 133; e "General Theory of the Neuroses." SE 16, p. 318.

${ }^{14}$ FREUD. "An Autobiographical Study." SE 20, p. 37.

15 Veja, por exemplo, FREUD. “Three Essays on Sexuality.” SE 7, p. 226 e MASSON, Jeffrey. Ed. The Complete Letters of Sigmund Frend to Wilhelm Fliess: 1887-1904. Trad. Jeffrey Masson. Cambridge: 1985 , p. 272. 


\section{A Mulher Fala: ou $O$ que é um enigma?}

Nos anos 1950, Lévi-Strauss introduziu uma leitura que desorganizou ainda mais a posição das palavras da Esfinge. Ele propôs que um enigma em um mito funciona como "uma questão que é postulada enquanto não tendo resposta (...) Essa inversão produz uma resposta para a qual não bá nenbuma pergunta."16 Nesse sentido, a Esfinge, como um interlocutor direto, é silenciada, numa ideia que ganhou força considerável. Ela é utilizada, por exemplo, pelos estudos feministas, quando autores como De Lauretis fecham a possibilidade de um enigma não resolvido: "De qualquer modo, se Édipo não decifra o enigma, então o enigma não é mais um enigma; ele permanece um enigma estruturalmente insolúvel enquanto indecifrável." 17 Ao afirmar isso, a autora consagra Édipo como o limite da comunicação, dispensando assim a especificidade do enigma. Na seara da escola clássica, Vernant, citando LéviStrauss, investiga a possibilidade desse enigma

ser entendido como uma questão isolada de sua resposta, ou seja, formulada de tal maneira que esteja além do alcance humano, não podendo a resposta ser conectada a ele. O enigma, na verdade, representa um defeito ou uma impossibilidade de comunicação no diálogo de dois interlocutores. ${ }^{18}$

Mas se, como Badiou nos lembra, "o que um conhecimento paciente deseja e procura (...) é que nada seja indecifrável", ${ }^{19}$ não seriam essas destituições imprudentes? Em que ponto alguém desiste ou para de pensar sobre um determinado assunto? Não é perigoso fazê-lo no caso de uma troca importante - mesmo que problemática - entre um homem e uma mulher? Em particular, em uma troca na qual é permitido que o "ele" derrote o "ela" ou na qual o "ele" enfrenta uma impossibilidade, estando a incapacidade "dele" em compreender o significado "dela" encerrada para a leitura?

Novamente, levar adiante a análise de Lévi-Strauss pode resultar na fuga do conteúdo do enigma. Todavia, levar em conta a sugestão de Vernant a respeito de um defeito de comunicação, ao invés de uma impossibilidade de comunicação, pode também alertar para a hipótese de ser a brecha entre a pergunta e a resposta desses interlocutores exatamente o que mereça uma investigação mais profunda. Assim, apesar da afirmação de Lévi-Strauss sugerir

\footnotetext{
${ }^{16}$ LÉVI- STRAUSS, Claude. Structural Anthropology 2. Trad. Monique Layton. London: 1978, p. 22.

${ }^{17}$ LAURETIS. Alice Doesn't: feminism semiotics cinema. 1984, p. 156.

${ }^{18}$ VERNANT, Jean-Pierre. “ The Lame Tyrant: From Oedipus to Periander.” In: VERNANT, Jean-Pierre. VIDAL-NAQUET, Pierre. Myth and Tragedy in Ancient Greece. Trad. Janet Lloyd. New York: 1988, p. 208. A partir deste ponto abreviado como "LT."

${ }^{19}$ BADIOU, Alain. Being and Event. Trad. Oliver Feltham. London: 2005, p, 314.
}

50 fragmentum, N. 38, Vol. 2. Laboratório Corpus: UFSM, Jul./ Set. 2013 
produtivos caminhos de reflexão, não se pode ignorar esta outra possibilidade: talvez a alegação de que um enigma não pode ser resolvido indique a recusa em perceber a perspectiva de quem o profere. O problema pode refletir uma incompatibilidade de sensibilidades, uma perspectiva empobrecida do interlocutor que responde. A propósito, nosso fascínio com esse tema é fato do herói em questão ser conhecido por sua tendência a ignorar, a esquecer, o papel crítico desempenhado por seu interlocutor, estando, portanto, num impasse. Assim, ao invés de adiar um exame mais profundo do enigma ou relegá-lo ao abismo da impossibilidade, vamos considerar o enigma do ponto de vista da Esfinge, numa mudança para a perspectiva feminina. No contexto de uma observação mais próxima do monstro, perguntamos: revelaria o próprio enigma algum outro segredo ou mistério?

\section{Quem é a Esfinge?}

É com a morfologia do corpo da Esfinge que estamos mais familiarizados, tendendo a riqueza e a complexidade do imaginário mitológico que a circunda a serem ignorados. Se isso, em alguma medida, tem a ver com a sua feminilidade, então outros elementos, como seu corpo ${ }^{20}$ e sua monstruosidade - ao lado da marginalização da sua subjetividade, de seu contexto, de sua história e de sua posição discursiva - recebem, infelizmente e previsivelmente, rara atenção.

Enquanto a esfinge grega comumente tem um rosto de mulher, corpo de leão, e asas de pássaro (Apolodoro, A Biblioteca de Mitologia Grega, 3.5.8) ou raramente seios de mulher ${ }^{21}$ e outras características animais como cauda de serpente, a Esfinge de Tebas é fortemente marcada por mais um traço: além do corpo, mas decorrente dele, ela fala com uma voz humana. Ela tem uma linguagem, uma lógica e um intelecto; este último, inclusive, de uma espécie superior (Eurípides, As Fenícias, v. 48). Em seu aspecto humano, a Esfinge é precisamente uma mulher adulta com quem se pode conversar: poderia ser de alguma significância o fato de que ela incorpora essa colisão de monstro e sujeito feminino discursivo?

As leituras do mito que buscam uma compreensão da condição quase humana da Esfinge comumente ignoram sua capacidade de falar e reduzem sua posição a uma figura materna ameaçadora, pós-freudiana, na verdade, a uma

\footnotetext{
${ }^{20}$ Essa ênfase no corpo é reforçada quando a "imperfeição física" de Édipo é alocada como a própria resposta ao enigma da Esfinge. Veja, por exemplo, LÉVI-STRAUSS, Claude. Structural Anthropology. Trad. Claire Jacobson e Brooke Grundfest Schuepf. Hammondsworth: 1977, p. 215 e VERNANT, "LT," p. 207-36.

21 Veja MORET, Jean-Marc. CEdipe, la Sphinx et les Thébains: Essai de Mythologie Iconographique. 2 vols. Rome: 1984, vol. 2.
} 
descrição kleiniana. ${ }^{22}$ Nesse sentido, se, quando a Esfinge é identificada como figura humana ou como representação disso, ela for reduzida à figura maternal malévola, isso de modo algum constitui a implantação de uma posição subjetiva. Antes, apenas dispensa a necessidade de abarcar sua posição de sujeito parcialmente humano, subordinando assim sua característica mais marcante - aquela do intelecto humano e da fala - à dimensão do maternal. Ademais, essa ênfase desloca as narrativas mitológicas em que ela é apresentada. No mito grego, o jogo de significados recebidos e propostos é inseparável de outras facetas do contexto mítico anterior. Se a constituição e as palavras da Esfinge forem divorciadas deste contexto, muito se perde.

A Esfinge de Tebas entra em cena como coadjuvante, como remissão externa e passada, na peça de Sófocles - o ponto de intersecção com o complexo de Freud - via dois caminhos: um é a sua história, como era contada nos anos da tragédia ateniense; o outro é a série de transposições que esse mito sofrera durante os milênios anteriores. A Esfinge não está em Tebas como produto da história de Édipo - ela tem a sua própria missão. Na versão mais detalhada, ela é enviada a Tebas por Hera, deusa do casamento, para punir os tebanos devido ao crime de Laio - ou seja, o do próprio pai de Édipo - por sequestrar e abusar sexualmente do menino Crisipo. Este episódio, que precede o nascimento de Édipo, coloca a sua história em movimento. Laio foi amaldiçoado por Pelops, o pai do jovem atacado, e os deuses em decorrência disso decretaram que Laio morreria por um ataque de seu próprio filho (Ésquilo, Sete contra Tebas, v. 720-820). ${ }^{23}$ Essa pré-edipiana história pregressa do mito significa que, na medida em que o papel da Esfinge era instaurar retribuição aos tebanos, ela significa reconhecimento e justiça contra o abuso sexual de crianças. Édipo, neste contexto, é justamente marcado por um lodaçal de incesto entre gerações e transgressão sexual. Sob esta ótica, o mito é bem anti-freudiano, ${ }^{24}$ pois administra vingança contra aqueles que ignoram os abusos pregressos enquanto Freud chega perigosamente perto de desculpar os 22 Goux, em sua longa discussão sobre "O Rito da Esfinge", a posiciona repetidamente como
figura materna e como ameaça mortal, evitando mencionar o fato peculiar de que ela pode
conversar. Veja OP, p. 40-59. Uma dissertação sobre o seriado de televisão dos anos sessenta
Mister Ed dificilmente estaria completa sem uma discussão sobre o fato de que aquele cavalo
falava. Ver Mister Ed, dir. Arthur Lubin et al.
${ }^{23}$ Veja também a nota explicativa de Robin Hard em Apollodorus. The Library of Greek Mythology.
Trad. Robin Hard. Oxford: 1998 , p. 225 , nota 106 .
${ }^{24}$ Esse ponto também não é respondido pela interpretação de Nietzsche sobre o papel da Esfinge.
O filósofo equaciona a "ambígua Esfinge" com a "natureza", e esta, por sua vez, com o crime de
incesto. NIETZSCHE, Friedrich. The Birth of Tragedy and The Genealogy of Morals. Nova York: 1956 ,
p. 60-1.

52 fragmentum, N. 38, Vol. 2. Laboratório Corpus: UFSM, Jul./ Set. 2013 
responsáveis ao constituir as próprias crianças como envolvidas em fantasias ficcionais. ${ }^{25}$

Este desígnio é, talvez, um pouco difícil de conciliar com a Esfinge, se sua função primordial for representar o aspecto ameaçador do maternal. A Esfinge é fortemente marcada pela associação com entidades femininas, que carregam variados e complexos significados. Além de sua aliança com Hera, ela está associada com as Fúrias (Eurípides, As Fenícias, v. 1500-5) e também com as musas que, como se diz, lhe ensinaram o enigma (Apolodoro, $A$ Biblioteca de Mitologia Grega, 3.5.8). Ela habitava um reino marcado por uma mescla do humano e do divino, enquanto entidades femininas exibiam desejo e ações vigorosas. Deusas gregas não deviam nada à paixão, à razão e às hábeis estratégias de suas contrapartes masculinas - não sendo nem um pouco classificadas como maternais. Os monstros femininos exibiam traços similares, sobretudo nas suas tentativas de subjugar aspirantes a heróis. Diferentemente, a Esfinge possuía uma subjetividade, um intelecto e uma sensibilidade: ela tanto propôs o enigma quanto respondeu emocionalmente à solução proferida por Édipo.

No entanto, por trás da Esfinge de Tebas, há muitas outras esfinges. Ela teve uma carreira encurralada a propósito de seu gênero - a anterior Esfinge egípcia era masculina, ${ }^{26}$ comumente um simples amalgama da cabeça de um faraó e do corpo de um leão. Na tradição pré-helênica cretense e grega ela se tornou feminina, adquirindo outras características humanas e animais. ${ }^{27}$ Não há nenhuma história associada com as esfinges egípcias, embora elas sejam frequentemente inscritas com o nome de um soberano específico. ${ }^{28}$ Anteriores esfinges gregas são apresentadas em caixões e tumbas; sendo seu papel simplesmente o de "escoltar os mortos", ecoando anteriores práticas funerárias egípcias. ${ }^{29}$ Mas a feminina Esfinge grega passou por mudanças significativas quando se mudou para o Monte Citeron.

25 O abuso sexual de crianças é um crime que predomina em nossas sociedades - suas
consequências sobre as vítimas funcionando como um enigma que frequentemente temos
interpretado mal. Por exemplo, o diagnóstico de "transtorno de personalidade borderline" deveria
ser revisto em relação ao complexo transtorno de estresse pós-traumático, em especial devido à
alta incidência de abuso sexual precoce no histórico médico de muitas das mulheres que
apresentam esta constelação de sintomas angustiantes. Essa direção desloca a ênfase da patologia
da mulher para a severidade do contexto de estresse, refinando com isso tanto o diagnóstico
quanto o tratamento. Veja, por exemplo, McLEAN, Linda M. e GALLOP, Ruth. "Implications of
childhood sexual abuse for adult borderline personality disorder and complex posttraumatic stress
disorder." American Journal of Psychiatry 160.2. February 2003, p. 369 .
${ }^{26}$ Joyce Tyldesley menciona uma única Esfinge feminina com a cabeça da comumente poderosa
amante de um faraó. Veja TYLDESLEY, Joyce. Daughters of Isis: Women of Ancient Egypt. London:
1994, p. 201.
${ }^{27}$ MacKENZIE. Donald A. Myths of Crete and Pre-Hellenic Europe. London, 1918: p. 295.
${ }^{28}$ MONTET, Pierre. Eternal Egypt. Trad. Doreen Weightman. London: 1965, p. 259.
${ }^{29}$ VERMEULE, Emily. Death in Early Greek. Art and Poetry. Berkeley: 1979, p. 69. fragmentum, N. 38, Vol. 2. Laboratório Corpus: UFSM, Jul./ Set. 2013 


\section{A Esfinge Mutável}

$\mathrm{Na}$ verdade, a outra história da Esfinge diz respeito às transformações que ela experienciou no decorrer do tempo dentro do imaginário mitológico grego. Tais mudanças denunciam a transação verbal que ela orquestrou com Édipo, mudanças diretamente entrelaçadas àquelas da própria sociedade. Midgley conclui que as mudanças no mito muitas vezes prenunciam transformações sociais: "Eles alteram o mito a fim de comprometerem a si próprios a mudar uma realidade mais ampla, sendo essa a maneira em que as mudanças sérias são eventualmente trazidas à luz." ${ }^{30}$ Se Édipo é posicionado como o modelar sujeito ocidental, então, à luz das mudanças sofridas pela Esfinge até o seu desenlace edipiano, pode-se afirmar que a criatura tebana é mais fortemente marcada por esta alteração do que seu interlocutor.

Enquanto a "função mais geral" da Esfinge "no decorrer de toda a antiguidade clássica é agir como um cão de guarda em uma sepultura ou coluna mortuária como punição àqueles que perturbam os mortos", ${ }^{31}$ dentro do registro pictórico há uma mudança. Nele, as esfinges são muitas vezes flagrantemente e perigosamente eróticas - perigosas predadoras sexuais de homens jovens. ${ }^{32}$ Embora ainda estejamos culturalmente interessados nessas características, ${ }^{33}$ o elemento erótico da esfinge é o que pavimenta o caminho para o papel do enigma da Esfinge tebana no mito e, na verdade, para a sua aquisição de uma voz humana e de um intelecto. Como observa Vermeule

o tema de uma esfinge de rapina foi popular e importante para a reflexão grega sobre a mortalidade. $\mathrm{O}$ ato de amor pode ser um ato de morte. Indiferente de ser doloroso ou prazeroso, para os gregos, tal ato era geralmente instrutivo. ${ }^{34}$

É neste contexto que a Esfinge de Tebas se torna uma instrutora quando começa a falar. "A Esfinge passa boa parte de sua vida artística conversando com rapazes, com Édipo ou com outros jovens tebanos, propondo a eles enigmas sobre o que a vida e a maturidade poderiam ser quando eles ainda são tão inexperientes para compreendê-las." ${ }^{35}$

\footnotetext{
${ }^{30}$ MIDGLEY, Mary. The Myths We Live By. London e New York: 2003, p. 175.

${ }^{31}$ VERMEULE, Death in Early Greek, Art and Poetry, p. 171.

32 Ibid.

33 Goux, por exemplo, tanto enfatiza a sexualidade da Esfinge quanto a privilegia como sua principal característica humana, não aludindo a sua voz. Veja $O P$, p. 36-7 e 64.

34 VERMEULE, Death in Early Greek, Art and Poetry, p. 173.

${ }^{35}$ Ibid., p. 171.
}

54 fragmentum, N. 38, Vol. 2. Laboratório Corpus: UFSM, Jul./ Set. 2013 
Algumas pinturas cerâmicas retratam esse encontro como um combate mortal, com Édipo matando a Esfinge com uma espada ou lança, ${ }^{36}$ num modelo similar ao relato escrito de Corinna. ${ }^{37}$ Nesses, o confronto toma sua forma habitual. Todavia, excepcionalmente no caso de Édipo e a Esfinge o combate dá lugar à versão em que o monstro é proponente de enigmas. Neste caso, o encontro transforma-se em um "teste de linguagem" (OP, p. 59) e o poder físico do monstro é ampliado, a fim de incluir um comando de intelecto, de palavras e de vontade. Assim, no final do século VI, na medida em que é assimilada ao mito iniciatório de Édipo, a Esfinge torna-se um ser inteligente e discursivo. 38

Enquanto a Esfinge tebana mata aqueles que falham diante de seu desafio, inicialmente seu desafio não repousa nem em brutalidade nem em sedução sexual. Neste caso, a agenda cultural é verbal e é ela que introduz este novo estilo, que parcialmente afasta o ritual do combate terrível, aproximandoo do diálogo. Portanto, ela iniciar estes novos termos de transição entre a antiga e a nova forma é o que inclui o papel de Édipo, não o contrário. Ela, como Édipo, é uma aberração, uma figura pós-tradicional que introduz diferenças em uma cultura mais antiga. ${ }^{39} \mathrm{Em}$ algum momento, há uma mudança - registrada dentro da forma mítica como uma iniciação feminina -, que parte do modo heróico dos atos corajosos e sangrentos para chegar à dimensão do discurso. Bem antes de meados do século V, quando Oedipus Rex foi apresentado pela primeira vez, ela tornou-se uma Esfinge totalmente moderna.

\section{Uma Iniciação Perversa: Quem é Édipo?}

A importância dada por Freud ao mito edipiano alocou-o como "universal", consagrando tanto a história quanto o herói como entidades fixas - moldadas por um inconsciente trans-histórico e trans-cultural. Todavia, Édipo, assim como a Esfinge, é produto de um campo mais fluido de significados mitológicos. Em vista disso, a afirmação da universalidade do mito torna-se, no mínimo, controversa. ${ }^{40}$ Ademais, como apontado por Goux, este

\footnotetext{
${ }^{36}$ See MORET, Edipe, la Sphinx et les Thébains: Essai de Mythologie Iconographique, vol. 2, p. 63.

37 Albert Schachter comenta este aspecto na versão de Corinna para o mito. Veja The Oxford Companion to Classical Civilization. Ed. Simon Hornblower e Antony Spawforth. Oxford: 2004. Verbete "Sphinx."

${ }^{38}$ Veja MARCH, Jenny. Cassell's Dictionary of Classical Mythology. London: 2001, verbete "Sphinx."

39 As sereias apresentam algumas características comuns com a Esfinge: elas são figuras compostas de pássaro e mulher; elas têm uma voz musical; as palavras de suas canções são algumas vezes mencionadas; e em algumas versões, elas morrem por suicídio. Todavia, nenhum diálogo face a face com o herói é elaborado. Veja, por exemplo, HOMERO. Odisséia. Canto 12, versos 188-191.

${ }^{40}$ Embora Goux observe que embora o "monomito do herói masculino, um mito protótipo de investidura monárquica", possa ser encontrado em muitas culturas (Goux, OP, cap. 5) e que
} 
mito é atípico, sobretudo em seu próprio contexto grego. E é precisamente o parricídio e o incesto - eventos que Freud clama como modelares do desejo humano universal - que o marcam como um dos mitos mais incomuns de seu tipo $(O P$, p. 8-12, 19). Para os gregos, era justamente essas irregularidades o mais significativo. ${ }^{41}$

Goux identifica uma sequência narrativa dentro dos mitos gregos de iniciação heroica - como, por exemplo, os de Péricles, Belerofonte e Jasão. Nesses, o herói é rejeitado por seu pai, o rei, que o vê como uma ameaça; à beira da idade adulta, ele encontra um segundo rei que o desafia com uma prova potencialmente mortal; o herói aceita o desafio, um confronto com um terrível monstro feminino, o que efetua um teste tríplice ao provar sua coragem em combate, sua habilidade em resistir à sedução sexual e sua capacidade em manter sua determinação mesmo em circunstâncias adversas; com a ajuda de um deus, comumente Atena, ele vence o monstro; por fim, é recompensado com uma "noiva princesa", a filha de um terceiro rei cujo reino ele herda (OP, p. 6-8.).

Édipo começa a sua história da maneira usual. Após seu nascimento, seu pai, com medo de uma profecia segundo a qual ele morrerá às mãos do filho, deixa-o exposto para morrer. Édipo é encontrado e levado para outra família real. A partir deste ponto, apesar da remissão comum à estrutura modelo, cada alteração no enredo mítico apresenta uma variação carregada de significado. Não havendo desafio lançado por um segundo rei, Édipo acidentalmente mata seu próprio pai, quando, em um acesso de raiva, ele golpeia até a morte um homem velho que bloqueia seu caminho. Ele então encontra a Esfinge e responde ao enigma usando apenas seu intelecto para vencer o desafio. Não há combate, nem a necessidade de continência sexual, muito menos a solicitação de uma intervenção divina: ele encontra a Esfinge apenas como um homem. Em decorrência deste encontro, a Esfinge se suicida. Por este embate, Édipo não recebe a mão de uma princesa, mas a da rainha viúva Jocasta, o que o faz ascender ao trono de Tebas - desconhecendo assim o matrimônio com sua própria mãe, com quem terá quatro filhos.

Na verdade, segundo Goux, na sua forma edipiana o mito iniciatório é invertido: ele passa a representar a falha ou a fuga da iniciação masculina, levando o herói a experienciar uma perversão da conclusão mítica tradicional

Dumézil tenha identificado traços particulares de um enredo monomítico no universo IndoEuropeu (Goux, $O P$, cap. 4), essas formas míticas trans-culturais não são perpassadas pela ocorrência de parricídio e incesto (cap. 1).

${ }^{41} \mathrm{O}$ mito e o complexo de Édipo são comumente caracterizados como "universais", embora, na verdade, o enigma da Esfinge possa encerrar uma reivindicação ainda mais forte desta posição. Além de não ser exclusivo ao corpus grego, ele tem sido identificado em várias culturas. Veja EDMUNDS, The Sphinx in the Oedipus Legend, p. 18, e Frazer em Apollodorus. The Library. Trad. Sir James George Frazer, 2 vols. Cambridge: 1967, p. 347. 
(OP, capítulos 1 e 4). Subversões da forma ocorrem em outros mitos heróicos. Todavia, aqui essas subversões se estendem hiperbolicamente. A partir desta perspectiva, a afirmação de Freud de que um desejo universal de parricídio e incesto conduzem a trama perde o seu ponto. Parricídio e incesto são marcadores de diferença neste mito. Eles se relacionam com a problemática sócio-histórica que esse mito particular, e igualmente o drama homônimo de Sófocles, apresenta: a transição de um determinado tema de uma sociedade tradicional para uma pós-tradicional. ${ }^{42}$

A vitória de Édipo sobre a Esfinge repousou na valorização secular da sua inteligência. Nessa perspectiva, o desafio enigmático não está inserido na estrutura dos temporais ritos de passagens que conduzem da juventude à vida adulta: ou Édipo foi em direção a Esfinge ou ela própria decidiu bloquear o seu caminho. Aqui, os membros de uma família ou de uma casa real são colocados fora de seus papéis tradicionais e dentro de um quadro existencial de um "homem comum" ou de uma "mulher comum". Isso é enfatizado pelo não-reconhecimento de Édipo de seu pai e de sua mãe. Édipo se inclina assim à posição de um herói que caminha em direção a um sujeito autônomo, secular e pós-tradicional, a um sujeito que se afasta de suas contrapartes em outros mitos gregos. Neste sentido, Édipo assumiu as liberdades e os riscos de um sujeito democrático.

\section{As Mulheres, a Morte e o Medo de Voar}

A frágil condição de Édipo como herói triunfante está ancorada em seu momento de coragem conceitual na medida em que ele decifra o enigma. A fragilidade de tal vitória é revelada pelas consequências do mito e na forma como este foi explorado pelas tragédias. Posteriormente, com Freud, essa falha especificamente edipiana foi negligenciada. A Esfinge, todavia, é sempre vista como derrotada e sua morte é entendida como reflexo deste fracasso. $\mathrm{Na}$ verdade, porém, diferente de outros monstros, ela decide seu próprio destino. Em sua jornada através de várias transmutações míticas, o advento da troca verbal significa que sua morte não pode ser encarada como um fim previamente destinado. É dela a sua própria saída de cena, quando se lança de um penhasco rochoso, em algumas versões do mito em direção ao abismo. ${ }^{43}$ No contexto grego, a forma da sua morte não é destituída de significado.

Loraux aponta que as mortes de mulheres na tragédia ateniense, e portanto nos mitos que as inspiram, são de dois modos diversos. Um é o da virgem que morre pela espada, comumente num ato sacrificial. $O$ outro é a morte por enforcamento, o suicídio de uma esposa. A respeito do primeiro, a

\footnotetext{
42 Veja, por exemplo, a introdução de Bernard Knox para "Édipo Rei” em Sophocles. Three Theban Plays. Trad. Robert Fagles. Middlesex: 1984, p. 138-142.

43 Veja, por exemplo, Diodorus 3, p. 21-23.
} 
autora observa que para resolver a "discrepância entre o real e o imaginário" a prática ateniense do sacrifício animal e o sacrifício de virgens nas tragédias havia uma tendência generalizada em metaforicamente "animalizar virgens condenadas". ${ }^{4}$

Loraux encontra nos suicídios de mulheres uma penetrante ligação temática entre enforcamento e queda: "A queda do alto de uma rocha ou a queda para a forca não apresenta diferença alguma." (TW, p. 19). A "queda", por sua vez, está ligada à ideia do vôo de um pássaro - o jogo desses significados explica a inerente tensão no caso de uma criatura alada que decreta sua própria morte por meio de uma queda. A análise de Loraux associa o tropo do "vôo" com o ato de escapar ou fugir, com o ser "dominado pelos acontecimentos" (TW, p. 18) e com o silêncio (TW, p. 21-23). Tal morte é escolhida apenas por heroínas que "são muito femininas" (TW, p. 19). Estar pendurado denota, nesse contexto, mais a morte de uma mulher do que a morte de uma mãe (TW, p. 14-15). A mulher que se enforca está inserida no contexto de seu relacionamento com um homem, com um marido. "Pouco antes de a mulher saltar para o vazio, é a própria presença ausente do homem que ela sente pela última vez, em cada canto do thalamos" (TW, p. 24).

Portanto, a passagem de uma morte por assassinato sangrento para um suicídio por queda poderia marcar a mudança significativa na posição da Esfinge como um sujeito feminino. Se for assim, a morte de uma Esfinge que fala relaciona-se ainda mais fortemente com seus elementos humanos do que as suas características animais, além de marcá-la mais como uma esposa do que como uma virgem ou mãe. ${ }^{45}$ Ela morre do mesmo modo que um sujeito feminino adulto - o matrimônio era o que marcava a maturidade para os gregos de ambos os sexos (TW, p. 42). Orquestrando sua morte deste modo, a Esfinge situa a si própria e Édipo como sujeitos correspondentemente maduros e sexuais. Assim, enquanto a leitura habitual aponta para o suicídio da Esfinge em razão da perda de sua posição, sendo portanto efetivamente morta pelo herói (Eurípides, As Fenícias, v. 129), esta morte auto-imposta pode sugerir outros significados. Se Édipo veio a falhar grandemente em seus posteriores testes de maturidade, a Esfinge encena a morte de uma mulher madura em relação a um homem. Esse significado molda o sentido das suas transformações e também o sentido do seu enigma.

Se escapar de uma repetição cíclica de assassinato e violência é o que motiva a Esfinge, se ela for a iniciadora de uma mudança, a emissária e a própria agente de uma basilar alteração cultural, então isso fornece um

\footnotetext{
${ }^{44}$ LORAUX, Nicole. Tragic Ways of Killing a Woman. Trad. Anthony Forster. Cambridge: 1987, p. 34. A partir deste ponto abreviado como "TW."

${ }^{45}$ Loraux considera a morte de Antígona por enforcamento como uma exceção advinda do paralelo com o casamento, um paralelo que sua história apresenta de forma tão próxima. Veja $T W$, p. 31-32.
} 
contexto particular para o seu suicídio. Se de fato Édipo falhou em responder ao seu enigma, ela estaria prestes a matá-lo, até mesmo a devorá-lo. Mas o que dizer da hipótese de uma resposta parcialmente correta? Se ele tivesse se aproximado de forma mais íntima do que os muitos jovens que vieram antes dele, talvez esse encontro fosse para ela um dilema. Talvez, nos termos de Loraux, ela desejasse fugir, sendo, todavia, "esmagada pelas circunstâncias" e silenciada. Decepcionada no seu esforço em traduzir um rito sangrento em diálogo, ela opta por uma morte inegavelmente singular. A linguagem de algum modo pode ter falhado com ela, restando a Esfinge encenar sua própria opressão, ${ }^{46}$ recorrendo a um comportamento simbólico, como as mulheres têm feito no decorrer de milênios - o que mais corresponderia à histeria percebida por Freud? O esquema edipiano não funciona para as mulheres pósséculo XIX, talvez nem funcionasse para as mulheres dos tempos antigos - ou para o monstro que as representou.

\section{A Falha Trágica: a Heterossexualidade Socializada}

$\mathrm{Na}$ medida em que Édipo e a Esfinge conversam, eles ampliam as barreiras da forma tradicional, ambos confrontando um recebido modus operandi. Esse elemento é geralmente apresentado como um contexto importante para o herói - mas não para a Esfinge. Ela é figurada como animal sacrificial, como homem, como criança, como objeto erotizado, como objetivação maternal, como quebra-cabeça ou, ainda, como abstração em si mesma, mas nunca como representante do sujeito feminino lutando com as mesmas tensões como Édipo. Assim, a possibilidade de que a dinâmica heterossexual socializada possa estar em desacordo com a transformação do herói em um anthropos, em um homem - até mesmo dramatizando o lugar do seu possível fracasso - nunca é colocada em jogo.

Todavia, dada a intensificação da posição do monstro como oponente feminino bumano ou como interlocutor e a perversa ênfase na interação heterossexual que seguirá a Édipo, tal leitura não pode ser negligenciada. Parece prudente usá-la para enquadrar uma tentativa de compreender qualquer anomalia residual, qualquer dificuldade persistente, na resolução do evidente fracasso de Édipo em relação à sua "vitória" sobre a Esfinge. Afinal, os gregos não eram estranhos a esse problema. A sutileza da análise de gênero em obras como Antígona, Medeia e Lisístrata dialoga com as nossas sensibilidades

\footnotetext{
${ }^{46}$ Como Irigaray sugere, o termo "masquerade" pode ser "entendido como aquilo que a mulher faz para recuperar algum elemento de seu desejo, para participar do desejo masculino, porém, pagando o preço de renunciar ao seu próprio desejo." Veja IRIGARAY, Luce. "Questions". In: The Irigaray Reader. Trad. Catherine Porter e Carolyn Burke. Ed. Margaret Whitford. Cambridge: 1991, p. 135.
} 
contemporâneas. O pensamento grego estava se movendo em novas direções. Blundell apontou que

em torno da segunda metade do quinto século pensadores conhecidos como sofistas argumentavam que os valores e as instituições que foram tidas como estabelecidas pela "natureza" não passavam na verdade de construtos sociais, numa abordagem que muito pode ter influenciado o questionamento dos dramaturgos sobre as convencionais distinções de gênero. ${ }^{47}$

A história de Édipo orbita um desconhecimento que está intimamente entrelaçado com uma mudança em direção a uma subjetividade póstradicional. $\mathrm{O}$ mito traduz a adesão do herói adolescente à maturidade em um confronto existencial e subjetivo, lidando com um potencial cenário social nãoestruturado. Édipo, por não reconhecer seu pai, abate de forma ignominiosa o velho anônimo. Cego para a identidade de sua mãe, Édipo se casa apartado da segurança do modo tradicional. $\mathrm{O}$ monstro que bloqueia seu caminho enquanto ele se move da primeira cena para a segunda aborda-o verbalmente de sujeito falante para sujeito falante, um debate, não um combate. Supostamente, o herói desvenda a resposta a esse enigma.

Neste sentido, Édipo, assim como seu companheiro de viagem posterior, Freud, é louvado como aquele que "sabe". Porém, enquanto a sua resposta lhe trouxe a posição de herói, ela não fez nada para atenuar o precipitado progresso em direção ao seu trágico des-reconhecimento. Ele vai ao encontro do casamento, do leito e do engravidar sua própria mãe, por fim encontrando-se como o objeto de sua própria investigação criminal. Essa progressão sugere fortemente, como Goux enfatiza, que alguma coisa deu errado no seu encontro com a Esfinge. ${ }^{48}$ As falhas de Édipo são geralmente atribuídas a um erro de caráter, erro que produz tanto a possibilidade de um sujeito pós-tradicional quanto a sua tragédia. Essa leitura não será questionada aqui, embora a natureza dessa falha ou falhas precise ser discutida. O que proponho é seguinte: que existe uma sequência contínua, não interrompida, de des-reconhecimentos que inclui a própria Esfinge; que a falha que impede o reconhecimento seja, na verdade, bastante evidente; por fim, que é neste ponto que a possibilidade de uma formadora liberação ética do sujeito e de sua sociedade transforma-se em uma estase agorafóbica, incestuosa talvez.*

\footnotetext{
${ }^{47}$ BLUNDELL, Sue. Women in Ancient Greece. Cambridge, Mass.: 1995, p. 181.

48 Veja, por exemplo, OP, p. 199. Ao final, Goux encontra na impiedade a explicação para a "falha" de Édipo e seus subsequentes desastres - uma exagerada confiança na razão ao invés de uma deficiência intelectual. Veja $O P$, p. 14-15.

* Nota do Tradutor. A expressão utilizada pela autora - "agoraphobic (...) stasis", que traduzimos por "estase agorafóbica" - merece um detalhamento. "Estase" é um termo técnico utilizado em
} 
$\mathrm{Na}$ medida em que o mito aborda as dificuldades do sujeito em confrontar seus limites existenciais sem a mediação de estruturas sociais ou religiosas, a resposta de Édipo ao enigma - "o homem" - se encaixa muito bem. Ela retrata a vida de uma pessoa marcada não por parâmetros divinos, sociais ou parentais, mas por fatores intrínsecos ao próprio indivíduo. O herói solitário engatinha, caminha e em seguida manca através de uma existência definida em termos de espaço, de tempo e de sua própria corporeidade. Tal resposta espelha o movimento de uma subjetividade ainda impregnada por forças divinas e estruturas sociais tradicionais para outra de caráter existencial - como é evidente na atmosfera de anonimato que permeia as interações de Édipo com seus pais, parênteses externos do episódio do enigma.

No entanto, não existiria resposta alguma se não existisse pergunta; e é justamente a Esfinge que propõe a pergunta. Isso não tem peso algum nas leituras do mito, sendo a iniciativa feminina diretamente abarcada pelo interlocutor masculino. Goux pergunta: "Não seria Édipo, ao prefigurar e tipificar o destino grego, quem intelectualiza o encontro terrível e angustiante a tal ponto de o enigma, uma prova de linguagem, tornar-se o único e aceitável momento da passagem iniciatória?" (OP, p. 59). Goux adverte-nos ainda de que "não devemos esquecer o significado da resposta" (OP, p. 74). Mas e quanto à pergunta? $\mathrm{O}$ fato de ser a Esfinge que configura o conteúdo não tradicional do enigma e de ser ela a instigar as condições para um tipo de mudança - propondo evitar a violência brutal e apelar ao intelecto e ao diálogo - passa despercebido, o que constitui um significativo ponto cego dentro da tradição ocidental. As alterações do mito, porém, enfaticamente marcam este fator.

Presumivelmente, essa leitura tem sido tão fortemente evitada em virtude da "alteridade" da Esfinge impedir a criação de pontos de identificação e de crítica, problema não extensível às outras personagens do mito. Há,

três diferentes contextos. Nos manuais fisiológicos, significa o interrupção do fluxo normal de sangue ou retenção desse e de outros fluidos. Nesse contexto, também pode ser usado como sinônimo de "entorpecimento", "estagnação" ou "paralisia". Para a biologia evolucionista, "estase" significa os longos períodos nos quais as espécies animais não apresentam mudanças adaptativas marcantes. Por fim, em psicanálise, "estase da libido" refere ao acúmulo de energia libidinal, energia que encontra vazão nos sintomas neuróticos, chistes, esquecimentos, sonhos, atos falhos, etc. Quanto ao termo "Agoraphobia”, a psicanálise o relaciona com o medo de lugares abertos ou públicos, uma vez que a ágora grega era justamente o espaço da troca, do debate, das incertezas, um lugar tanto para a construção de si mesmo quanto da dissolução dos limites em relação ao outro. Nessa acepção, "estase agorafóbica" refere a um estado de estagnação psíquica no qual um desejo de proteção uterina impede o sujeito de sua liberação ou desenvolvimento em relação ao desconhecido. Se pensarmos que Édipo nunca deixa a casa paterna e materna e que seu percurso "heróico" é o de justamente retornar à cidade, a casa, ao leito, ao corpo familiar, tal relação fica mais evidente. A sugestão de Connell de que tal "estase agorafófica" possa indicar uma relação incestuosa ganha agora maior amplitude, uma vez que se trata de um mito como o de Édipo, personagem enredado na malha familiar e incapaz de abandonar a relação maternal primeira. Aqui, registro meu agradecimento à pesquisa e aos comentários de Rafael Dotto Scremin. 
porém, uma livre e ocasional tentativa de identificação por parte dos poetas, ${ }^{49}$ mas nada além disso. De Lauretis, por exemplo, chega perto:

O fato é que neste momento da história são as mulheres, as feministas, que falam do lugar da Esfinge, e quem olham para Perseus enquanto Medusa está sendo abatida, o que pode não ser compatível com o paradigma estrutural hegeliano. Mas então, isso significaria que a ordem moral do significado e o regulamento da lei do patriarcado não teriam mais relação com aquelas nas quais a mulher estaria se constituindo como sujeito. ${ }^{50}$

Em outras palavras, para se identificar com a Esfinge devemos imaginar algo que está além de nossa experiência anterior... ou senão iremos apenas compreendê-la quando ela estiver seguramente envolta nos pronunciamentos dos leões teóricos da tradição ocidental. Sua monstruosidade seria então apresentada em uma versão revista do quase irreconhecível, numa estratégia que impede o reconhecimento empático. Por que não evitar tais ponderações de tremor e objetivar uma identificação mais direta? A Esfinge pode ter algo a dizer sobre essas questões.

\section{Uma Insuficiência de Perspectiva: o Enigma}

Aqueles que propõem que ainda não resolvemos a Esfinge e seu enigma deixam a resolução do problema ao futuro - talvez outro grande homem intervenha. $\mathrm{O}$ enigma residual raramente é justaposto à leitura mais simples - aquela que ressalta as terríveis consequências sofridas por Édipo devido à sua inegável falha em satisfazer completamente o desafio. A própria Esfinge oferece a este libertador e transitivo ponto de virada uma interessante perspectiva. Em vista disso, não deveríamos reconsiderar as próprias palavras do seu enigma? A hipótese de que o enigma está perdido na resposta de Édipo é estranha. Todavia, talvez seja ainda mais estranho que, enquanto vários relatos do mito apresentem duas diferentes e significativas formas do enigma, esse fenômeno desperte pouco comentário e praticamente nenhuma interpretação. Essa poderia representar uma omissão como qualquer outra passagem do texto, mas no caso de um enigma tal omissão é extraordinária.

Uma versão qualifica a Esfinge como tendo "uma voz" enquanto a outra ignora essa informação. As versões mais comumente citadas, a de Apolodo

49 Veja, por exemplo, RUKEYSER, Muriel. "Private Life of the Sphinx". In: The Collected Poems of Muriel Rukeyser. New York: 1978, p. 278-9, e YEATES, W. B. "The Double Vision of Michael Robartes". In: W. B. Yeats Selected Poetry. Ed. A. Norman Jeffares. London: 1974, p. 86-8. ${ }^{50}$ LAURETIS, Alice Doesn't: feminism semiotics cinema, p. 210, nota 76. 
O que é que tem apenas uma voz, além de quatro, dois e três pés? ( $A$ Biblioteca de Mitologia Grega 106)

e a de Ateneu (4:569), mantêm a referência que é igualmente incluída na mais literária versão encontrada na scholia alexandrina das Fenícias de Eurípides.

Há na terra um ser com dois, quatro e três pés e uma única voz que, sozinho entre os que se movem pelo solo, pelo ar e pelo mar, muda sua natureza. Mas quando ele caminha com a ajuda de mais pés é quando seus membros são menos firmes. ${ }^{51}$

O relato de Diodoro (3:21) omite essa única voz. Estácio, que escreve uma descrição particularmente gráfica da Esfinge assassinando e devorando jovens tebanos, omite qualquer menção às palavras do enigma (1:433).

O enigma continua a ser citado de uma forma ou de outra, mas no geral é omitida a referência à "voz". ${ }^{52}$ Como veremos, essa é uma deturpação do corpus grego, que funciona para ajustar as palavras femininas à resposta masculina. Quando a expressão "uma só voz" é mencionada, é geralmente ignorada. Apagamento que coloca a resposta de Édipo como o primeiro exemplo da subsequente e estranha tradição da denegação.

Nas raras ocasiões em que a expressão recebe comentários, a falha de Édipo em responder ao enigma é ignorada. Ao invés disso, há uma recorrente tradição menor de explicação. Nela, essa voz única é lida como única "essência", ou seja, como uma criatura. Isso é intrigante, pois o uso da forma singular não requer nenhum esclarecimento sobre sua natureza unitária e o deslizamento interpretativo de "uma voz" para "uma essência" não tem base alguma. Tal alteração não se justifica nem em termos linguísticos ou filológicos nem nos termos do corpus clássico sobrevivente. Alguns estudiosos mais recentes têm se preocupado com isso. Robin Hard não discute abertamente o assunto, embora observe que a ligação entre voz e essência seja "obscura", permanecendo, portanto, inexplicada..$^{53}$ Isso é o mais próximo que chegamos

\footnotetext{
${ }^{51}$ Veja a tradução de Vernant em "LT," p. 468, nota 20.

52 LEMPRIÈRE, J. Lemprière's Classical Dictionary. London: 1984, verbete "Sphinx." Fontes que referem ao predomínio trans-cultural e trans-histórico deste enigma desconsideram completamente a ocorrência de duas diferentes formas.

53 Veja HARD. Greek Mythology, p. 225, nota 106. Vernant mantém a interpretação tradicional reconhecendo essa dificuldade ao aventurar a nova explicação de que enquanto todas as outras criaturas "vivem e morrem dentro de uma única modalidade de locomoção, o homem é o único que muda o seu modo de se mover... O homem é um ser que tanto permanece o mesmo (ele tem uma única voz, phone, uma única essência) quanto se transforma em outro.” Essa interpretação talvez seja apenas um pouco escorregadia no que se refere à borboletas e sapos. Veja VERNANT, "LT", p. 214.
} 
do reconhecimento de que esta frase poderia ser um problema, um enigma. Poderia não, é.

Estamos lidando, então, com palavras que foram relegadas ao extrasistêmico - apesar delas serem absolutamente intra-sistêmicas. O que devemos fazer com a anulação de uma das linhas de um poema curto inserido no mais notório enigma a ser registrado na história da nossa civilização? Édipo e Freud são ambos parte dessa elisão - Édipo por ignorar a expressão e Freud por reformular todo o enigma. Entretanto, não fomos nós ensinados pelo próprio Freud sobre a importância de atentar a tudo o que é dito ao invés de selecionar de acordo com os nossos preconceitos? Ou ainda mais, de que toda censura pode conter exatamente aquilo que é mais importante?

Se a constante repetição dessa supressão a partir de uma perspectiva edipocentrica for colocada de lado, chegamos à análise de um esquecido detalhe de tal enigma que foi condenado ao abismo do descaso. E o contexto no qual o enigma é inserido - um momento único em um diálogo que acontece entre um herói e um monstro - certamente sugere que a referência à voz mereça atenção especial.

Entretanto, se a expressão "uma única voz" é aqui recuperada para análise - e uma leitura inclusiva da expressão não é imediatamente óbvia -, isso se dá justamente por causa de uma antiga e comum dificuldade, uma dificuldade que, em si mesma, explica o ponto cego que obscurece a resposta. ${ }^{54}$ Trata-se da supressão do feminino que evidencia tanto o erro de Édipo quanto a subsequente marginalização da "única voz" do enigma.

É consenso de que o enigma se refere às mudanças de desenvolvimento que ocorrem durante o período da vida humana, ou seja, a infância, a vida adulta e a velhice. Ora, o rito iniciatório do herói é também uma marca de uma mudança significativa: fundamentalmente, é a respeito do fim da adolescência e da entrada na dimensão da responsabilidade social.

${ }^{54}$ Há enigmas nos tempos recentes que jogam com este ponto cego. Por exemplo: Um homem é
morto e seu filho sofre um ferimento na cabeça em um acidente de automóvel. Quando a criança é
levada ao pronto-socorro a pessoa responsável pela neurocirurgia diz: Não posso operar esse
menino, ele é meu filho. Como isso é possível? (Nota do tradutor: O desafio aqui proposto, em
língua inglesa, diz respeito ao "gênero" do responsável pela cirurgia. Como em inglês a palavra
"neurosurgeon" é comum de dois gêneros, o enigma é possível e a resposta é a "mãe do menino
ferido". Em português, precisamos fazer um contorcionismo estilístico - e portanto, com óbvios
resultados artificiais - para suplantar o gênero por meio de "a pessoa responsável pela
neurocirurgia", uma vez que "cirurgião" ou "cirurgiã" guia a resposta de dois modos: levando-a ao
absurdo das hipóteses possíveis que flertam com a própria fantasmática masculina de traição e
suspeita - o homem morto não sabia que seu filho tinha outro pai -, ou que entregam a resposta: a
mãe da criança acidentada. O exemplo de Connell é eficiente em ilustrar o ponto cego discursivo
na sua leitura do enigma e sua associação com as questões de gênero, sobretudo em vista da
supressão do sujeito feminino.) 
Édipo é, sobretudo, um herói adolescente. ${ }^{55}$ A Esfinge estabelece seu próprio desafio, de acordo com a forma tradicional, nos limites das aspirações do herói à maturidade. Ela olha para Édipo, ela contempla esse adolescente. Ter consciência da perspectiva do sujeito que pergunta fornece uma abrangente explicação daquilo que Édipo representa e ainda mais.

Se uma criatura tem uma só voz, então não se trata de uma criatura que tem mais de uma voz. Metade da raça humana tem mais de uma voz no decorrer de sua vida e um desses é o próprio Édipo. A voz de um macho adolescente "quebra": ele tem no decorrer de sua vida duas vozes bem diferentes. A forma mais longa do enigma inclui uma referência à adolescência, a fase de desenvolvimento que está justamente em questão na relação tradicional entre o monstro e o herói. Assim, a resposta a esta versão do enigma não é o "homem", como afirmado por Édipo, mas a "mulher". ${ }^{56}$

\section{Vida sem Esfinges}

A partir desta perspectiva, Édipo estaria apenas parcialmente correto. Ele teria passado quanto fracassado no teste. Como um teórico, estava indo razoavelmente bem, mas a cegueira de seu gênero impediu seu sucesso. Sua limitada resposta extirpou o feminino, ignorando a pista que estava diante de seus olhos - a voz humana da Esfinge. Para ele, as modalidades de locomoção e a capacidade de usar o simples complemento de uma muleta marcam adequadamente a todos nós como humanos. A voz, que ainda melhor nos diferenciaria das outras criaturas, foi ignorada, apesar da anomalia da criatura que estava diante dele. Linguagem, inteligência e vontade, qualidades que nos permitem refletir sobre o despertar da tirania da existência e com as quais tomamos nossa posição dentro da sociedade civil, não foram contempladas pela resposta de Édipo. ${ }^{57} \mathrm{Na}$ medida em que a Esfinge confronta o herói, ela

\footnotetext{
${ }^{55}$ Isso é abundantemente claro no registro pictórico. Veja, por exemplo, Vermeule, Death in Early Greek. Art and Poetry, p. 171, e Moret, Edipe, la Sphinx et les Thébains: Essai de Mythologie Iconographique, vol. 1, cap. 2.

${ }^{56}$ Que a palavra usada para "voz", $\varphi \omega v \eta$, tem um significado primário de som ou tom só pode adicionar peso a esta proposição. Veja LIDDELL, Henry George e SCOTT, Robert. Greek-English

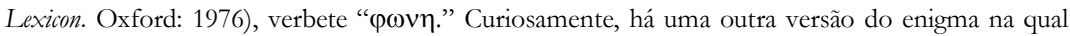
não há menção à "voz", mas que inclui a informação de que trata-se de um "ser" que "muda seu grito" (itálico meu). Esta pode ser uma alternativa à versão mais longa a propósito da resposta "homem". Ver VERNANT, "LT", p. 468, nota 20. Sobre isso, foi um poeta que, dando a Esfinge a posição de sujeito, chegou mais próximo a esta resposta - apesar de ainda perder o significado da referência à voz. Rukeyser apresenta um segundo encontro entre Édipo e a Esfinge, que diz ao herói que a sua resposta estava errada, uma vez que ele não dissera nada sobre a "mulher". Édipo protesta dizendo que a palavra "homem" inclui a "mulher": "todo mundo sabe disso". Em resposta, a Esfinge lhe diz: "Isso é o que você pensa". Veja Rukeyser, "Myth", p. 498.

${ }^{57}$ Vernant usa o enigma para se referir aos estágios físicos e sociais da "infância, da idade adulta e da velhice", diferenciando, assim, o ser humano das outras criaturas e mantendo, como o próprio
} 
se posiciona como uma locutora e como uma criatura insurrecta dentro de uma transação tradicional, formulaica, altamente marcada pelo gênero. Esse mistério, inserido em um enigma maior, jaz nas conseqüências da política de gênero: esta molda o desafio que a Esfinge propõe ao jovem homem - um aspecto no qual Édipo não é sábio. Ela propõe a inclusão, a não exclusão, do sujeito civil feminino e adulto na formação da estrutura tradicional. Todavia, não foi ouvida e, talvez, ainda não tenha sido ouvida.

Assim como a cena do enigma representa o ponto de articulação entre o herói e o anthropos, essa denegação marca os passos das gerações seguintes. Édipo, ao perder a chance de reconhecer o feminino discursivo, ascende ao trono mostrando-se no processo ineficiente para o próximo desafio. Diante desse des- reconhecimento, como encontrar uma mulher adulta que não seja a sua própria mãe? $\mathrm{O}$ desconhecimento da mãe, a incapacidade de diferenciar entre a mãe e a parceira, resulta de um perigoso ponto cego que advém, em primeiro lugar, de uma profunda angústia em relação à possibilidade de um feminino como sujeito equivalente, como sujeito auto-reflexivo. Diferente de outros heróis, Édipo toma em matrimônio uma mulher mais velha, diferente da jovem filha de um rei. Porém, no fim, as possibilidades dessa união são destruídas pela recusa em dissociar maturidade de maternidade.

$\mathrm{Na}$ medida em que se apropria da Esfinge para o seu esquema edipiano, Freud quase entrega o jogo devido às hiperbólicas consequências de sua denegação: Por qual razão seria o gênero da Esfinge tão problemático a ponto de necessitar de uma supressão? Por lê-la como um homem, Freud repete o erro original e desastroso do próprio Édipo. ${ }^{58}$ Depois, ao afirmar que a curiosidade infantil centra-se no "mesmo enigma proposto pela Esfinge tebana", não "a respeito da questão sobre a distinção entre os sexos mas o enigma sobre a origem dos bebês" (grifo meu), Freud indiretamente propõe a própria resposta ao enigma da Esfinge por negá-la, a ponto de mudar a pergunta a fim de evitar sua resposta. ${ }^{59} \mathrm{~A}$ reescrita freudiana da pergunta aponta para uma única resposta possível, para a mulher como mãe: na verdade, Freud segue os

Édipo, os modos de locomoção como principal identificador. A voz seria um melhor candidato a referir ao mundo social bumano. Veja "LT", p. 214-5. A expressão "sozinho (...) muda a sua natureza", na versão encontrada na scholia da tragédia de Eurípides poderia referir à capacidade do sujeito auto-reflexivo de alterar os hábitos recebidas.

${ }^{58}$ Nietzsche também se baseia na cena do enigma quando formula a ideia de um eterno retorno. Nas duas transposições da cena do enigma evocadas nesta passagem - a tabuleta do anão que bloqueia o caminho de Zaratustra no alto de uma estrada pedregosa e no encontro entre Zaratustra e o pastor, no qual um enigma é proposto -, novamente os interlocutores são apresentados como exclusivamente masculinos. Se a mulher está presente, é apenas como a serpente que tem "mordido a si própria com rapidez", dentro da garganta do pastor, ou seja, como um mudo e silenciado monstro. Veja NIETZSCHE, Friedrich. Thus Spake Zarathustra. Trad. Walter Kaufmann. England: 1966, p. 155-60.

${ }^{59}$ Strachey aponta essa confusão, a de que a "questão primária" vacila entre assuntos de gênero e de origem. Veja FREUD. “The Sexual Enlightenment of Children.” SE 9, p. 135, nota 2. 
passos de Édipo e os de seus sequenciais desconhecimentos. Ambos estão fadados a encontrar a mãe diante do feminino adulto, isso porque é a adolescência psíquica do feminino que eles são incapazes de reconhecer - sua maturidade dissociada de suas funções sexuais e procriativas. Na verdade, são as especificidades e as possibilidades de um diferente modelo de transição de puberdade feminina que são eclipsadas pela resposta incompleta ao enigma e pelo Complexo de Édipo. A "uma voz" do enigma refere-se à puberdade como transição diferenciada para a menina - mas não nos termos de sua sexualidade. Essa "uma voz" potencialmente desatrela a transição da puberdade social no caso de todos os sujeitos das necessidades de violência e de transmissão de um poder autocrático, acenando para uma puberdade de pensamento e de linguagem como modos cruciais para acessar a maturidade.

O enigma postula precisamente a importância de se recusar a hegemonia da identificação do masculino heróico ou másculo e de se atentar à transição adulta feminina que nunca foi retratada como percurso brutal para a glória heróica.

Mais recentemente, não necessariamente escapamos dessas armadilhas. Quando estudos feministas utilizam a Esfinge em suas críticas, uma leitura mais próxima de suas palavras e das diferentes formas de seu enigma é ignorada enquanto a suposição de que ela seria uma auto-evidente representação do maternal é difundida - às vezes, isso inclui a tentativa de situá-la como representante de uma anterior sociedade matriarcal, ${ }^{60}$ numa hipótese um pouco traiçoeira, dada à sua masculina pré-história. Todavia, privilegiar o sujeito feminino como maternal frequentemente funciona como forma de evitar a possibilidade de a mulher ter igual importância no imaginário como um representativo sujeito auto-reflexivo.

Apesar do argumento pontualmente desenvolvido por Goux, de que o próprio mito de Édipo explicaria as limitações do sujeito ocidental e do esquema freudiano, quando se trata da Esfinge sua linha de raciocínio é mais conservadora. Ele argumenta que outros heróis recrutam ajuda divina para matar um monstro feminino, evidentemente um símbolo de matricídio, para, assim, adquirir o status adulto de rei. É a recusa desse presumido matricídio que marca Édipo como um herói diferente. A derrota do monstro por Édipo apenas com a sua inteligência, efetuando uma "des-projeção" dos deuses e desse modo "apreendendo profundezas enigmáticas" recalcadas (OP, p. 201), representaria a figura da própria Esfinge. É esse inconsciente que Freud mais tarde "descobriria". Nesta acepção, o horrível incesto de Édipo ocorre porque a ausência de um matricídio impede a "libertação do feminino" - a disponibilidade da princesa ao herói é para Goux um não problemático modelo para tal libertação (veja, por exemplo, $O P$, p. 27, 38-9), além dessa

${ }^{60}$ Veja, por exemplo, MULVEY, Visual and Other Pleasures, p. 177-8. 
explicação não dissociar a filosofia ocidental de seu percurso de recalque. A única mulher adulta neste modelo é a princesa "libertada" em um matrimônio que cede o poder ao marido. A Esfinge, assim, torna-se primeiro a mãe, para em seguida, representar o inconsciente, ou seja, uma abstração sem voz (OP, p. 199). Com certeza, ver o feminino como um sujeito auto-reflexivo equivalente apresenta melhor base para um parceiro adulto do que produzir uma maturidade aparente calcada no assassinato de uma figura materna.

Goux, como Freud, chega muito perto de perceber a resposta inclusiva para o enigma da Esfinge:

O gesto pelo qual Édipo aponta a si mesmo de modo a responder à "cadela enigmática", guardiã do teste iniciatório, e a crença de que ele poderia vencê-la com a palavra "bomem" na sua presunção de autoiniciação, constituem, num efeito contrário, a diferença entre o que depois será chamado de consciência e inconsciência. (Itálico meu) (OP, p. 132-3)

Todavia, a recusa de Édipo em aceitar o feminino no enigma e na Esfinge passa despercebido e, para Goux, “a loucura de Édipo torna-se a racionalidade ocidental" (OP, p. 202). No entanto, se considerarmos a resposta mais abrangente para o enigma, também pode se dizer que a loucura de uma irracionalidade que justifica a prática diária de opressão limita o próprio alcance da racionalidade ocidental. Como Goux deixa claro

Ao situar a si próprio como ponto de vista no mundo, como a central e única medida de todas as coisas, o homem simultaneamente adquiriu a visão objetiva que decifra todos os enigmas, que acalma todos os terrores, que lança ao abismo todas as Esfinges. (OP, p. 129)

Entretanto, uma vida sem Esfinges - vivas e falantes como são, não aquelas descartadas como mães mortas residuais - pode significar uma vida empobrecida.

\section{Conclusão: Ser ou Não Ser um Poeta}

Há muito a se pensar se evitarmos a difundida visão freudiana a respeito de uma identificação masculina - e de uma hipotética feminina - com um Édipo universalizado e vermos a Esfinge não como monstruosa ou maternal, nem como sujeito feminino "universal", mas como representativa de uma mulher heterossexual socializada, que lida com a possibilidade da 
mudança assim como Édipo o faz. ${ }^{61}$ Tal leitura, a meu ver, estaria mais próxima da sabedoria do mito. Poderíamos com isso pensar que seriam justamente as falhas da estrutura social tradicional as responsáveis tanto pela resposta de Édipo ao enigma quanto pela resposta da Esfinge ao jovem herói. Disso, poderíamos perguntar: se a Esfinge relutou em matar, em devorar Édipo - como fez com os jovens que vieram antes dele, mas com os quais nenhuma reciprocidade de compreensão surgiu -, por que ela não manteve essa troca discursiva por mais tempo? Por que não o trouxe para perto de si, instruindo-o a respeito de seu erro? Talvez porque isso teria sido pedir muito, em muito pouco tempo. Como uma adversária, a Esfinge forçou os limites do rito de iniciação, situando-o parcialmente na linguagem e parcialmente no combate sangrento ou em uma fatal sedução. Todavia, a despeito de seu papel de tutora de jovens tebanos, numa situação não erotizada, ela estava impedida ou talvez ela mesma evitou manter de modo mais firme sua posição de instrutora, filósofa ou poeta. Como sua primeira tentativa de ser reconhecida como sujeito equivalente falhou, ela não mais se pronunciou. Ao invés disso, se ausentou, desistiu. Como resultado, tanto ela quanto Édipo sentiram pouco as possibilidades da libertação. Tais personagens nos levaram longe, mas não longe o bastante.

É concebível que a Esfinge, como um sujeito falante, não esteja mais ligada às suas identificações tradicionais com os corporais reinos da violência e do sexo, estando tampouco sujeita à aprovação masculina desse novo papel - e a resposta de Édipo ao seu enigma recusa a ela precisamente isso. A Esfinge permaneceu irreconhecível, deslizando da linguagem para a concretização do erro de seu interlocutor. Foi essa uma silenciosa tentativa de atrair a atenção deste interlocutor? Sua morte auto-infligida evidenciou o erro deste, sua rejeição a ela. Não que um tal sacrifício tenha resultado em qualquer benefício - Édipo adentrou em um horror caótico, deixando o terreno aberto para as insistentes representações de uma tradição não feminina. ${ }^{62}$ Quando a Esfinge

\footnotetext{
${ }^{61}$ Assim, a Esfinge também ilumina a nossa atenção a Antígona. As maquinações entre uma jovem e um perigoso homem mais velho se tornaram a principal alavanca para a análise das interações de gênero no contexto grego - suplantando justamente aquelas entre um garoto adolescente e uma perigosa mulher mais velha. Antígona sacrifica a si própria para honrar um homem impulsivo e violento. A Esfinge também encena uma forma de sacrifício por um homem inadequado, embora, diferente de Antígona, voluntariamente retire a si própria, um ato potencialmente mais desafiador em um status quo no qual tal suicídio acena para outros sentidos. E interessante que cada uma delas, embora não sejam casadas, está de acordo com o forma de morrer de uma esposa. Ambas morrem, por assim dizer, dentro de uma dinâmica heterossexual socializada - ou será que morrem em função dessa dinâmica?

${ }_{62}$ Talvez possamos fazer isso com a sequência de Édipo Rei, peça que está menos ligada à narrativa mítica do que a primeira e na qual a reabilitação de Édipo no final de sua vida resulta em novo modo de sucessão direta de rei para rei baseada na passagem de um "segredo". Veja a introdução de Bernard Knox para essa tragédia em Three Theban Plays. A mulher, neste caso, não é mais instrumento de passagem do poder de um pai para o marido, tampouco sendo apresentada na sua
} 
lançou-se ao abismo, levou consigo uma oportunidade - e a cultura não se livrou dessa inadequada reação. $O$ sintomático suicídio da Esfinge, sua onipresença em nossa tradição como uma resposta puramente "emocional" e a subsequente e devastadora acepção do triunfo e da superioridade de Édipo ainda figuram, infelizmente, como traços comuns das adaptações de gênero dentro de um espaço sócio-cultural.

Como o sangrento rito de iniciação foi traduzido em um encontro de angústia existencial, inexistia qualquer necessidade estrutural de o sujeito feminino não ser equivalente. Sófocles, em Édipo em Colono, reabilita Édipo após seu fracassado rito de passagem, dando-o outra chance: Mas por que não dar outra chance a ela? Se a Esfinge tivesse mais uma vez uma chance dela, evitando então a posição de vítima, isso lhe colocaria numa posição de maior responsabilidade, diminuindo um pouco a de Édipo. Neste caso, outras possibilidades poderiam ainda ser exploradas. Se ela e Édipo levassem adiante o seu diálogo, este poderia não ter superado a aporia entre os participantes, mas teria evidenciado a "universalidade" da importância de uma crise existencial. O fracasso diante do enigma demonstra a denegação generalizada diante da necessidade de uma crise como essa à maturidade masculina, feminina ou a de qualquer sujeito auto-reflexivo "diferente". Logicamente, este é um modelo melhor para a transição da adolescência à condição adulta do que a euforia passageira advinda do superficial triunfo sobre um outro objetificado.

Ao produzir uma catexia baseada na linguagem e no diálogo ao invés de na violência tal modelo alternativo pode antecipar-se à árdua tarefa de introduzir negociações verbais produtivas em áreas de entrincheirado e violento conflito social. O crítico período de desenvolvimento individual na história da nossa civilização pode não ser a presumida fase edipiana da infância, mas a da transição da adolescência, esta sim podendo ser mais apuradamente denominada de edipiana. O circuito de interações existentes entre Édipo e os outros personagens do mito, a maioria constituída em torno de sexo ou violência, produziu justamente a perpetuação da transgressão sexual e da violência. Há algo de apodrecido na transição inter-geracional, que se repetirá até que o problema seja reconhecido.

A resposta inadequada de Édipo ao enigma e o subsequente silêncio da Esfinge constituem um desperdício da possibilidade de reconhecimento. É o diálogo que demarcou uma possível saída deste persistente conflito, mas a capacidade deste herói para usar reflexão e linguagem a fim de escapar do ciclo de violência e opressão sexual era limitada. As tensões entre Édipo e a Esfinge oscilam entre a linguagem e a dispersão violenta dos corpos. Como um

função de prova ou teste de capacidade. Uma tradição menos violenta é inaugurada - embora o problema do feminino desapareça, apagando-se assim seu significado. O desafio sexual ou físico do ser feminino se foi, erradicado pelo único herói que experienciou a alternativa - o diálogo com a mulher - como um teste à sua maturidade, um teste com o qual não conseguiu lidar. 
significante da diferença de gênero, a "voz" sugere o imaginário como problemática de gênero em relação ao discurso, para além da referência a sexo e violência por si mesmos. As mudanças de conteúdo dentro da linhagem do mito, a bifurcação da forma do próprio enigma e a perda de uma de suas respostas, todas elaboram as instabilidades deste tema - e do próprio percurso da civilização ocidental.

A Esfinge também acessou suas limitações. Se estivesse mais confortável com a sua própria autoridade, poderia ter facilitado não apenas a desmistificação do pressuposto de que a violência e o assassinato são prérequisitos para a maturidade, mas também a consciência de que o padrão de gênero das políticas opressivas interpessoais associadas à forma tradicional era profundamente falho. Esses dois aspectos podem estar fatalmente conectados - e é isso que o Enigma da Esfinge comunica. ${ }^{63}$ Ele critica exatamente uma interação na qual o feminino interage apenas parcialmente: Édipo perde este ponto.

A Esfinge ofereceu a Édipo uma transição para a vida adulta com base no discurso reflexivo, um discurso que critica a prática objetificadora como um dos grandes riscos à estabilidade da sociedade civil; um modelo de maturação que poderia perturbar, mais do que reforçar, a transmissão dessa lógica problemática de geração a geração. Se vivêssemos dentro de outro imaginário - e enigmas chamam a atenção para isso tanto quanto para a nossa capacidade intelectual, sendo a falha de Édipo mais neste sentido do que no outro -, no qual a resposta ao enigma mais amplo fosse imediatamente óbvia, viveríamos uma diferente mentalidade, ou seja, numa diferente sociedade. ${ }^{64}$

Tradução de Enéias Farias Tavares e revisão de Rafael Dotto Scremin.

${ }^{63}$ De Lauretis postula um "remake dessa história" no qual se o enigma era insolucionável para Édipo, sendo, portanto, insolúvel, "a Esfinge não mataria a si própria num ato de auto-aversão... mas continuaria a enunciar o enigma da diferença sexual, da vida-e-morte, e da questão do desejo" (meu itálico). Alice Doesn't: feminism semiotics cinema, p. 156. A questão da diferença sexual apresenta sua hiper-carregada posição como um enigma, como o supremo significante de diferença, como o local pás excellence para interrogar o desejo, embora sua conexão possível com a problemática da posição comunicativa do feminino esteja perdida. O risco desta manobra é o de compensar com certo glamour teórico a posição da diferença sexual como um local primordial de perpetuação da objetificação e da prejudicial opressão na sociedade civil.

${ }^{64}$ Dentro da tradição ocidental, presumiu-se que a intervenção direta no que concerne ao corpo seria a "resposta" ao problema do excesso populacional quando, na verdade, o necessário seria igualar a oportunidade de acesso à educação, seria ver na mulher um sujeito comunicativo, não um corpo reprodutivo - fato primeiramente descoberto no conflito, para só então ser compreendido conceitualmente. 